\title{
Relationship Between Lipid Assessment and Arterial Lesions Observed in Farm Chickens Fed on Different Vegetable Oils
}

\author{
Mondé Aké Absalome ${ }^{1, ~ *}$, Lohoues Essis Claude ${ }^{1}$, Gauze-Gnagne-Agnero Chantal ${ }^{1}$, \\ Camara-Cissé Massara ${ }^{1}$, Diomandé Mohenou Isidore ${ }^{2}$, Djessou Sossé Prosper ${ }^{1}$, \\ Sess Essiagne Daniel ${ }^{1}$ \\ ${ }^{1}$ Medical Biochemistry Laboratory, School of Medical Sciences, University Felix Houphouet-Boigny, Cocody, Abidjan, Côte D’Ivoire \\ ${ }^{2}$ Pathology Laboratory of the University Hospital of Cocody, Abidjan, Côte d'Ivoire
}

\author{
Email address: \\ monde_abs@yahoo.fr (M. A. Absalome) \\ ${ }^{*}$ Corresponding author
}

\section{To cite this article:}

Mondé Aké Absalome, Lohoues Essis Claude, Gauze-Gnagne-Agnero Chantal, Camara-Cissé Massara, Diomandé Mohenou Isidore, Djessou Sossé Prosper, Sess Essiagne Daniel. Relationship Between Lipid Assessment and Arterial Lesions Observed in Farm Chickens Fed on Different Vegetable Oils. Journal of Food and Nutrition Sciences. Vol. 4, No. 5, 2016, pp. 126-130. doi: 10.11648/j.jfns.20160405.12

Received: September 11, 2016; Accepted: September 23, 2016; Published: October 11, 2016

\begin{abstract}
The objective of this study was to determine the relationship between lipid assessment ( total-cholesterol, HDLcholesterol, LDL-cholesterol, triacylglycerols) and arterial lesions in farm chickens fed on six different vegetable oil varieties (crude red palm oil, industrial red palm oil, refined palm oil, soya oil, cotton oil, and groundnut oil). The following emerged from the different analyses: palm oil, and, to a lesser extent, soya oil and cotton oil, tended to lower the total cholesterol rate whereas groundnut oil increased the rate. Groundnut oil raised highly triacylglycerols whereas soya oil and palm oil had the opposite effect. Red palm oil and cotton oil increased LDL-cholesterol rate whereas groundnut oil and soya oil tended to lower the HDL-cholesterol rate. Moreover, pathological anatomy studies demonstrated that arterial lesions were generally fewer, particularly among chickens fed on palm oil.
\end{abstract}

Keywords: Lipids, Total-Cholesterol, Farm Chicken, Vegetable Oils, Atherosclerosis, Palm Oil

\section{Introduction}

Atherosclerosis is responsible for the majority of deaths in developed countries, with death occurring especially because of ischaemic heart pathologies and / or ischemia stroke [1-3]. Multiple factors are causes of occurrence of the atherosclerosis, among which diet rich in fat and cholesterol plays an undeniable part $[2,4]$. In Africa, the atherosclerosis has a low incidence rate, which could be attributed to the diet which is less rich in fats compared to the Western diet. However in the higher social-class, the incidence of atherosclerosis tends to rise. Dietary lipids are obtained from vegetable or animal sources. Among these oils, palm oil extracted from the pulp of oil palm fruits which is commonly used particularly in West Africa, and in Asia in general, could be mentioned $[5,6]$. Some studies $[1,7,8]$, have shown that the consumption of palm oil, which is rich in monounsaturated and polyunsaturated fatty acids, has antiatherogenic properties. However, many studies have been interested in palm oil, in particular those carried out in Malaysia in humans as well as in animals [6-9]. We have previously shown the antioxidant effects of palm oil, the phenolic compound implication in vitro, with human LDLvitamin $\mathrm{E}$ oxidation and their effects in menopausal women [10-13]. However, in West Africa French-speaking countries, few studies were interested in the antiathero genic effects of palm oil, especially from the experimental viewpoint. It is therefore interesting, in such a context, to study the relationship between lipidic assessment and pathological lesions on arteries of farm chickens fed either on cotton, soya, groundnut or palm oils. This species has the advantage of being omnivorous and can develop a spontaneous human- 
like atherosclerosis [14].

\section{Experiment}

\subsection{Biological Samples}

Chicken (Gallus domesticus) is a good animal model research having plasma levels of cholesterol and triacylglycerols similar to those of humans, with chylomicrons of high and low density, and lipoproteins resembling those of humans [14]. The experiment was constituted of 300 chickens divided into six batches of 50 each. Thus, batch 1 was composed of 50 chickens fed on cotton seed oil; batch 2 fed on traditional red palm oil (TRO); batch 3 fed on industrial red palm oil (IRO); batch 4 fed on yellow refined palm oil (RPO); batch 5 fed on groundnut oil; and batch 6 fed on soya oil. All the 300 chickens selected were from eggs which had been put in an incubator on the farm site for 21 days.

The arterial samples obtained on day 30 and on day 90 were put in bottles containing neutral formol at $10 \%$ and were then taken to the pathology laboratory for examination with the optical microscopy.

\subsection{Composition of the Food}

During the experimental period, the chickens were fed on a standard diet prepared on the farm site. The diet was constituted of various mixtures called B1 and B2. B1 which was used to feed the chickens from day 1 to day 30 was composed of corn $(50 \%)$, oil, precisely $1 \%$ of each vegetable oil (15), lysin $(0.45 \%)$, flour $(16 \%)$, methionine $(0.15 \%)$, sodium chloride $(0.30 \%)$, sodium bicarbonate $(0.1 \%)$, cotton oil cake $(15.10 \%)$, corn bran $(0.9 \%)$ and shellfish $(16 \%)$. B2 on the other hand, was used to feed the chickens from day 30 to day 90 , and had the same alimentary constituents as B1 except for corn bran and the shellfish which were replaced by copra.

\subsection{Blood Sampling and Biological Examinations}

The blood sampling was carried out on days 30,60 and 90 . At the end of each experimental period, 10 chickens from each batch were killed. The blood obtained from the neck vein was kept in tubes containing heparin and then immediately taken to the laboratory under ice within 30 minutes following the blood sampling. The total cholesterol and triacylglycerols, serum levels were quantified by enzymatic methods in the LISA -BIO 200 Analyzer (Biomerieux, Lyon, France). The HDL-cholesterol levels were enzymatically determined in the supernatant after sodium phosphotungstate/ $\mathrm{MgCl}_{2}$ precipitation. The LDLcholesterol was calculated from the FRIEDWALD formula. The optical microscopy was used to carry out the pathological study.

\subsection{Statistical Analysis}

All statistical analyses were performed using the data- processing software epi-info approved by the WHO. To test the strength of the correlations between variables, the Pearson Correlation Test was used. The results are expressed as mean $\pm \mathrm{S}$.D and differences were considered significant when $P<0.05$.

\section{Results and Discussion}

\subsection{Changes of Lipids Parameters}

The data presented in Figure 1 indicates the changes of lipids parameters over time for different oils. The total cholesterol level of chickens fed on palm oil in all its forms regularly lowered from day 30 to day 90 , as did that of chickens fed on soya oil. On the other hand, the total cholesterol of chickens fed on groundnut oil increased during the same experimental period. Wilson et al. [8] reported that hamsters fed with various preparations of palm oil had a reduction in plasma cholesterol concurrently with less accumulation in arteries. The serum triacylglycerols were lowered in chickens which were fed on palm oil in all its forms (in agreement with findings of Kausar et al. [16]), cotton and soya oils. On the other hand, an increase of triacylglycerols was observed in chickens which were fed on groundnut oil. The HDL-cholesterol (Figure 1B) was increased in chickens which were fed on cotton and palm oils whereas in chickens fed on soya and groundnut oils, a decreasing trend of LDL-cholesterol was noted. Mensink et $a l$. [17] reported that the mechanism of this increase could be due to a rise in Apo A1 transport. However, we did not notice any significant difference between the rate of HDLcholesterol for chickens fed on palm oil and that of chickens fed on cotton seed oil. Poernama et al. [18] assessed the effect of HDL deficiency on diet-induced or spontaneous atherosclerosis in chickens and found that the highcholesterol diet did not elevate the plasma HDL-cholesterol concentration in either group. The LDL-cholesterol was lower in chickens which were fed on palm oil, but remained constant in chickens fed on cotton and soya oils. On the other hand, LDL-cholesterol levels increased noticeably in chickens fed on groundnut oil. The decrease of LDLcholesterol in the chickens fed on palm oil could be due to the enhancement of LDL receptors $[4,19]$. As the main part of LDL, cholesteryl esters might provide polyunsaturated fatty acids (PUFA) to cells efficiently via LDL receptor. It was assumed that PUFA in cholesteryl esters were closely correlated with the cholesterol metabolism and the atherosclerosis development by regulating the LDL receptor activity, the platelet function and the prostaglandin synthesis $[20,21]$. There is evidence that oxidatively modified LDL plays a crucial role in atherogenesis $[22,23]$.

Data presented in Table 1 shows the evolution of the HDL/LDL atherogenic index of chickens from day 30 to day 90. This index showed a significant fall in the HDL/LDL ratio in chickens fed on groundnut oil, whereas it was higher or constant for chickens fed on other vegetable oils. It is well known that the risk of coronary heart disease increases with 
higher LDL-cholesterol levels particularly when HDLcholesterol levels are low (16), indicating that the HDLcholesterol modifies the relationship between the LDLcholesterol levels and the cardiovascular risk [3, 24, 25].

\subsection{Relationship Between Nutrition and Arterial Lesions}

The pathological examinations for chickens arteries fed on the various varieties of palm oil were carried out in the arteries, such aorta, coronary arteries and cerebral arteries, which are the usual sites of predilection for the atherosclerosis [21]. The main goal of this pathological study was to determine a possible relationship between various oils and arterial lesions observed in these arteries. It has been noted that there is no essential difference between vascular lesions seen in chickens as a result of cholesterol diet and that of atherosclerosis observed in human [14].

Table 2 shows histological aspects of the arteries from day 30 to day 90 for chickens fed on different types of oil. Out of 180 chickens studied, only 29 (16\%) presented histological lesions, which suggests that these lesions were generally fewer in chickens fed on different varieties of oils. By comparing the arterial lesions, we noticed on day 30 that these lesions were practically tiny in our study. This tendency was confirmed on day 60 , but on day 90 we observed a slight increase of arterial lesions. There were overall, very few arterial lesions in spite of the diet, with the exception of chickens fed on groundnut oil.

Table 3 shows the correlation between the different types of arterial histological lesions and the type of oil from day 30 to day 90. The correlation test did not show a significant difference between the lesions and the various types of oils. On day 90, these results were not significant for the soya, cotton and palm oils but revealed a significant difference on day 90 for the groundnut oil; we noticed that in chickens having developed arterial histological lesions, the content of LDLcholesterol was higher, testifying that when the lipid assessment was disturbed, there was a strong probability of arterial lesions developing over time. However the lipid assessment of chickens fed on palm oil as well as cotton and soya oils did not undergo great variations; which enabled us to affirm that vegetable oil consumption, in general, lowered the incidence of the atherosclerosis, due to the richness of these oils in unsaturated fatty acids, attesting that vegetable oils exhibit a protective effect against atherosclerosis $[1,2,4]$.

Thus, palm oil presents the same benefits at the nutritional level as well as the histological level (on the arteries of chicken) as soya and cotton seed oils. Moreover, In addition to its numerous virtues, its high content of antioxidants and $\beta$-carotene plays a protective role in many pathologies including vitamin A deficiency, certain cancers and cardiovascular disease [26-28].

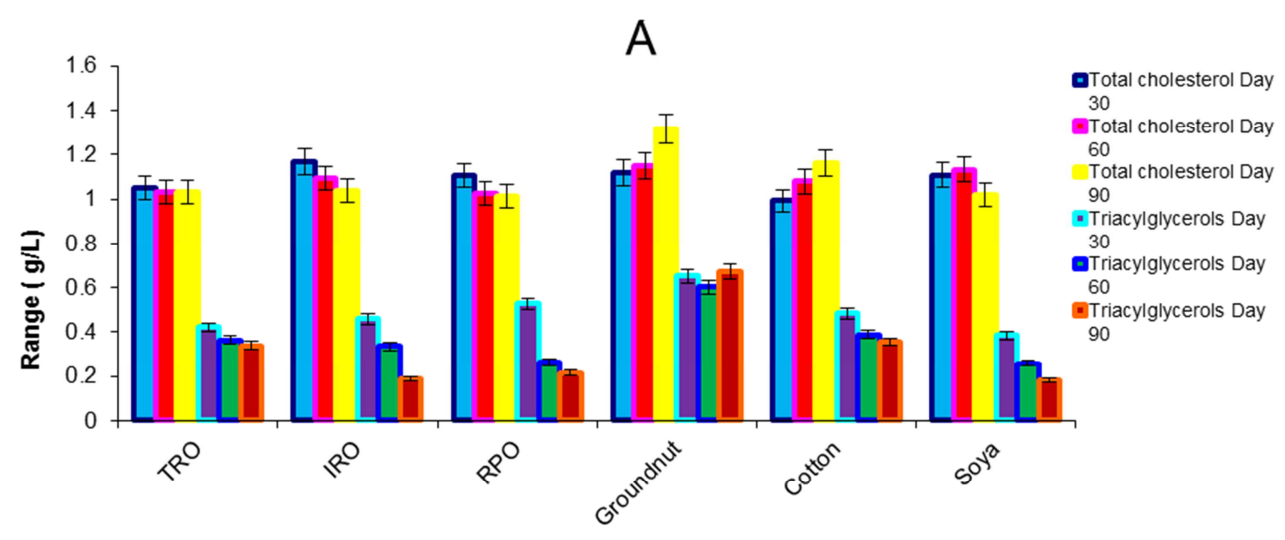

Varieties of oils

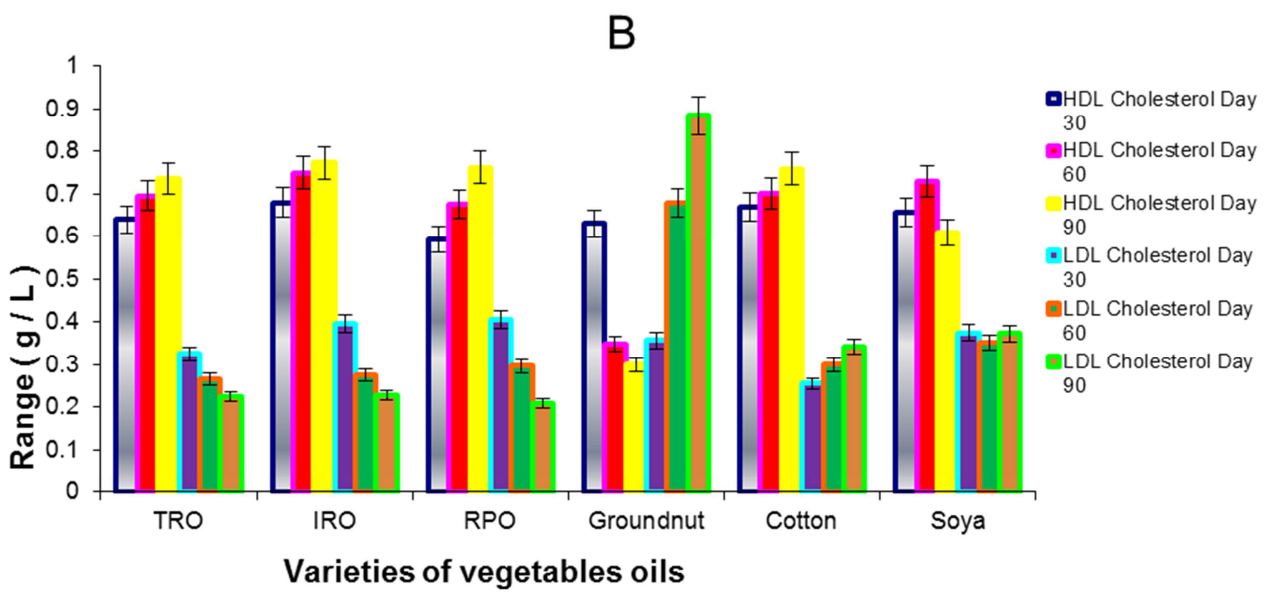

Figure 1. Changes of lipids parameters over time for vegetables oils. 
TRO: Traditional Red Oil; IRO: Industrial Red Oil; RPO; Yellow refined palm oil.

(A) Changes in total cholesterol and triacylglycerols rates; (B) Changes in HDL-Cholesterol and LDL-Cholesterol rates. Data are expressed by means values of triplicate experiments. Error bars indicate standard error of mean values.

Table 1. Evolution of the $H D L / L D L$ atherogenic index of chickens from day 60 and day 90.

\begin{tabular}{llll}
\hline \multirow{2}{*}{ Varieties of oil } & \multicolumn{3}{l}{ HDL / LDL Cholesterol Index } \\
\cline { 2 - 4 } & Day 30 & Day 60 & Day 90 \\
\hline Traditional Red Oil & 1.97 & 2.61 & 3.28 \\
Industrial Red Oil & 1.72 & 2.72 & 3.38 \\
Yellow refined palm oil & 1.46 & 2.27 & 3.65 \\
Groundnut Oil & 1.77 & 0.52 & 0.34 \\
Cotton Oil & 2.62 & 2.34 & 2.21 \\
Soya Oil & 1.75 & 2.07 & 1.64 \\
\hline
\end{tabular}

There was a significant fall in the HDL/LDL ratio in chickens fed on groundnut oil, whereas it was higher or constant for chickens fed on other vegetable oils.

Table 2. Histological aspects of the arteries from day 30 to day 90 for chickens fed on different types of oil.

\begin{tabular}{llll}
\hline Varieties of oil & \multicolumn{3}{l}{ Histological aspects } \\
\hline & normal aspect & Lesions & Total chickens \\
\hline TRO & 25 & 5 & 30 \\
Soya oil & 26 & 4 & 30 \\
RPO & 25 & 5 & 30 \\
IRO & 27 & 3 & 30 \\
Groundnut oil & 23 & 7 & 30 \\
Cotton oil & 25 & 5 & 30 \\
Total & 151 & 29 & 180 \\
\hline
\end{tabular}

TRO: Traditional Red Oil; IRO: Industrial Red Oil; RPO: Yellow refined palm oil.

Among 180 chickens studied, only 29 (16\%) presented histological lesions, suggesting that these lesions were generally fewer in chickens fed on different varieties of oils.

Table 3. Correlation between the different types of arterial histological lesions and the type of oil from day 30 to day 90.

\begin{tabular}{|c|c|c|c|c|c|c|c|c|c|c|}
\hline \multirow[t]{2}{*}{ Variety of oil } & \multicolumn{3}{|c|}{ Lipid Stria } & \multicolumn{3}{|c|}{ Lipid fibrosis } & \multicolumn{3}{|c|}{ Big lipid fibrosis } & \multirow[t]{2}{*}{ Total lesions } \\
\hline & Day30 & Day 60 & Day 90 & Day 30 & Day 60 & Day 90 & Day 30 & Day 60 & Day 90 & \\
\hline TRO & $1^{\mathrm{a}}$ & $0^{\mathrm{a}}$ & $1^{\mathrm{a}}$ & $1^{\mathrm{a}}$ & $0^{\mathrm{a}}$ & $2^{a}$ & $0^{\mathrm{a}}$ & $0^{\mathrm{a}}$ & $0^{\mathrm{a}}$ & 5 \\
\hline Soya oil & $0^{\mathrm{a}}$ & $0^{\mathrm{a}}$ & $2^{\mathrm{a}}$ & $1^{\mathrm{a}}$ & $0^{\mathrm{a}}$ & $1^{\mathrm{a}}$ & $0^{\mathrm{a}}$ & $0^{\mathrm{a}}$ & $0^{\mathrm{a}}$ & 4 \\
\hline IRO & $0^{\mathrm{a}}$ & $0^{\mathrm{a}}$ & $0^{\text {a }}$ & $0^{\mathrm{a}}$ & $1^{\mathrm{a}}$ & $2^{a}$ & $0^{\mathrm{a}}$ & $0^{\mathrm{a}}$ & $0^{\mathrm{a}}$ & 3 \\
\hline Groundnut oil & $0^{\mathrm{a}}$ & $0^{\mathrm{a}}$ & $3^{b}$ & $0^{\mathrm{a}}$ & $0^{\mathrm{a}}$ & $0^{\mathrm{a}}$ & $0^{\mathrm{a}}$ & $0^{\mathrm{a}}$ & $4^{b}$ & 7 \\
\hline Cotton oil & $0^{\mathrm{a}}$ & $0^{\mathrm{a}}$ & $1^{\mathrm{a}}$ & $0^{\mathrm{a}}$ & $0^{\mathrm{a}}$ & $4^{a}$ & $0^{\mathrm{a}}$ & $0^{\mathrm{a}}$ & $0^{\mathrm{a}}$ & 5 \\
\hline
\end{tabular}

TRO: Traditional Red Oil; IRO: Industrial Red Oil; RPO: Yellow refined palm oil.

Significant differences are shown by different letters $(P<0.05)$.

For all the oil types on day 30 and day $60: \mathrm{X}^{2}=101.41 \mathrm{ddl}$ $=3$ and $\mathrm{P}=0.134(>0.05)$ not significant difference.

For cotton, soya and palm oils on day $90: X^{2}=103.45 \mathrm{ddl}$ $=3$ and $\mathrm{P}=0.099(>0.05)$ no significant difference.

For groundnut oil on day $90: \mathrm{X}^{2}=122.42 \mathrm{ddl}=3$ and $\mathrm{P}=$ $0.000001(<0.05)$ significant difference.

The correlation test did not show a significant difference between the lesions and the various types of oils. On day 90, these results were not significant for the soya, cotton and palm oils but revealed a significant difference on day 90 for groundnut oil.

\section{Conclusion}

This study has revealed that the palm oil in all its forms has a cholesterol-lowering effect, triglyceride-lowering, while lowering the LDL cholesterol and increasing the HDL cholesterol, in chickens fed on this oil. Regarding the histological lesions, there was no significant difference between these lesions and the different types of oils $(\mathrm{P}=0.134)$ on day 30 and day 60. Moreover, the lipid assessment for chickens fed on palm oil did not undergo major histological perturbations over time, and this could lead us to suggest that the consumption of these oils helps reduce the incidence of atherosclerosis due to their high fatty mono and polyunsaturated acids. This oil, commonly used in Côte d'Ivoire and in many other countries, is one of the vegetable oils that has a protective effect against the atherosclerosis overall and proves to be an indispensable nutritional asset for populations both in its bioavailability and its affordable cost for all socioeconomic strata.

\section{Acknowledgements}

The authors express their sincere thanks to the Company COSMIVOIRE (SIFCA, SA, Abidjan, Côte D'Ivoire), for their invaluable contribution through the funding of this study. We also express our gratitude to Mr Professor JeanPaul Cristol, Mrs Dr Marie-Annette Carbonneau and Mrs Dr Françoise Michel for their contribution in the scientific improvement of this paper.

\section{References}

[1] D Kritchevsky, SA Tepper, SK Czarnecki and K Sundram. Red palm oil in experimental atherosclerosis. Asia Pac J Clin Nutr, vol 11, 2002, pp. 433-437.

[2] CM Williams, A Salter. Saturated fatty acids and coronary heart disease risk: the debate goes on. Curr Opin Clin Nutr Metab Care, 19 (2), 2016, pp. 97-102. 
[3] A Gikas, V Lambadiari, A Sotiropoulos, D Panagiotakos, S Pappas. Prevalence of major cardiovascular risk factors and coronary heart disease in a sample of greek adults: The saronikos study. Open Cardiovasc Med J, vol 10, 2016, pp. 69-80.

[4] SJ Hur, B Min, KC Nam, EJ Lee, DU Ahn. Effect of dietary cholesterol and cholesterol oxides on blood cholesterol, lipids, and the development of atherosclerosis in rabbits. Int $\mathrm{J}$ Mol Sci, vol 14 (6), 2013, pp. 12593-606.

[5] DO Edem. Palm oil: biochemical, physiological, nutritional, hematological, and toxicological aspects: a review. Plant Foods Hum Nutr, vol 57, 2002, pp. 319-341.

[6] K Sundram, R Sambanthamurthi, YA Tan. Palm fruit chemistry and nutrition. Asia Pac J Clin Nutr, vol 12, 2003, pp. 355-62.

[7] N Balasundram, TY Aï, R Sambanthamurthi, K Sundram and S Samman. Antioxidant properties of palm fruit extracts. Asia Pac J Clin Nutr, vol 14, 2005, pp. 319-324.

[8] TA Wilson, RJ Nicolosi, T Kotyla, K Sundram and D Kritchevsky. Different palm oil preparations reduce plasma cholesterol concentrations and aortic cholesterol accumulation compared to coconut oil in hypercholesterolemic hamsters. J. Nutr. Biochem, vol 16, 2005, pp. 633-639.

[9] N Wattanapenpaiboon and MW Wahlqvist. Phytonutriment deficiency: the place of palm fruit. Asia Pac. J. Clin. Nutr, vol 12, 2003, pp. 363-368.

[10] AA Mondé, MA Carbonneau, F Michel, C Lauret, S Diabate, E Konan, D Sess, J-P Cristol. Potential health implication of in vitro human ldl-vitamin $\mathrm{E}$ oxidation modulation by polyphenols deriving from Côted'ivoire's oil palm species. J. Agric. Food chem. Vol 59, 2011, pp. 9166-9171.

[11] AA Monde, MA Carbonneau, S Diabate, E Konan, D Sess, JP Cristol. Effets des extraits polyphénoliques d'huiles de palme dans l'oxydation in vitro des LDL par le cuivre. J. sci. pharm. Biol, vol 11 (1), 2010, pp.47-56.

[12] YF Djohan, AA Mondé, J Djinhi, G Koffi, G Niamké, L Déré, L Agniwo, G Tiahou, CM Camara, P Djessou, , D Sess. Effets antioxydants de l'huile de palme rouge traditionnelle chez la femme ménopausée en Côte d'Ivoire. Rev CAMES- Série A, Vol 11, 2010, pp. 22-25.

[13] A.A Monde, F Michel, M. A Carbonneau, E Konan, S Diabate., D Sess, J.P Cristol. Quantification et identification des composés phénoliques extraits de formes variétales d'huiles de palme rouge brute de Côte d'Ivoire. Rev CAMES - Série Pharm. Méd. Trad. Afr., vol 17(1), 2014, pp. 41-47.

[14] YM Chung, J Hyun Lee, D Youl Kim, SH Hwang, YH Hong, SB Kim, S Jin Lee, C Hye Park. Dietary D-psicose reduced visceral fat mass in high-fat diet-induced obese rats. J Food Sci, vol 77 (2), 2012, pp. 53-8.

[15] HY Yue, J Wang, XL Qi, F Ji, MF Liu, SG Wu, HJ Zhang, GH Qi. Effects of dietary oxidized oil on laying performance, lipid metabolism, and apolipoprotein gene expression in laying hens. Poult Sci, vol 90 (8), 2011, pp. 1728-36.

[16] H Kausar, G Bhasin, MA Zargar, M Athar. Palm oil alleviates
12-O-tetradecanoyl-phorbol-13-acetate-induced tumor promotion response in murine skin. Cancer Lett, vol 192 (2), 2003, pp. 151-60.

[17] RP Mensink, PL Zock, AD Kester and MB Katan. Effects of dietary fatty acids and carbohydrates on the ratio of serum total to HDL-cholesterol and on serum lipids and apolipoproteins: a meta-analysis of 60 controlled trials. Am J Clin Nutr, vol 77, 2003, pp. 1146-1155.

[18] F Poernama, R Subramanian, ME Cook and AD Attie. High density lipoprotein deficiency syndrome in chickens is not associated with an increased susceptibility to atherosclerosis. Arterioscler Thromb, vol 12, 1992, pp. 601-617.

[19] M Hoekstra, TJ Van Berkel, M Van Eck. BI Scavenger receptor: a multi-purpose player in cholesterol and steroid metabolism. World J Gastroenterol, vol 16 (47), 2010, pp. 5916-24.

[20] J Zhang, J Xu, J Wang, C Wu, Y Xu, Y Wang, F Deng, Z Wang, X Chen, M Wu, Y Chen. Prognostic usefulness of serum cholesterol efflux capacity in patients with coronary artery disease. Am J Cardiol, vol 117 (4), 2016, pp. 508-14

[21] JW Seo, EJ Yang, KH Yoo, IH Choi. Macrophage differentiation from monocytes is influenced by the lipid oxidation degree of low density lipoprotein. Mediators Inflamm, vol 2015, 2015, Article ID 235797, 10 pages. doi: 10.1155/2015/235797. Epub 2015 Jul 29.

[22] D Steinberg, S Parthasarathy, T Carew, JC Khoo and JL Witzum. Beyong cholesterol: modifications of low density lipoprotein that increase atherogenicity. N Engl J Med, vol 320, 1989, pp. 915-924.

[23] R Shrestha, SP Hui, Y Miura, A Yagi, Y Takahashi, S Takeda, $\mathrm{H}$ Fuda, H Chiba. Identification of molecular species of oxidized triglyceride in plasma and its distribution in lipoproteins. Clin Chem Lab Med, vol 53 (11), 2015, pp.185969.

[24] EJ Schaefer, P Anthanont, BF Asztalos. High-density lipoprotein metabolism, composition, function, and deficiency. Curr Opin Lipidol, vol 25 (3), 2014, pp. 194-9.

[25] SV Shah AM Shukla, C Bose, AG Basnakian, M Rajapurkar. Recent advances in understanding the pathogenesis of atherosclerosis in CKD patients. J Ren Nutr, vol 25 (2), 2015, pp. 205-8

[26] S Ishtiaque, $\mathrm{N}$ Khan, MA Siddiqui, $\mathrm{R}$ Siddiqi, S Naz. Antioxidant potential of the extracts, fractions and oils derived from oilseeds. Antioxidants (Basel), Vol 2 (4), 2013, pp.24656.

[27] BK Chen, B Seligman, JW Farquhar. Multicountry analysis of palm oil consumption and cardiovascular disease mortality for countries at different stages of economic development: 19801997. Global Health 2011, pp. 7:45.

[28] E Fattore, C Bosetti, F Brighent, C Agostoni, and G Fattore. Palm oil and blood lipid-related markers of cardiovascular disease: a systematic review and meta-analysis of dietary intervention trials. Am J Clin Nutrition, vol 99, 2014, pp. 1331-50. 